\title{
Correction to: Laïcité Unveiled: A Case Study in Human Rights, Religion, and Culture in France
}

\section{Melanie Adrian ${ }^{1}$}

Published online: 18 February 2021

(C) Springer Nature B.V. 2021

\section{Correction to: Human Rights Review (2006) 8: 102-114 https://doi.org/10.1007/s12142-006-1018-3}

The original version of this article unfortunately contained a spelling mistake in the title.

"La'icit" should read as "Laïcité".

The original article has been corrected.

Publisher's Note Springer Nature remains neutral with regard to jurisdictional claims in published maps and institutional affiliations.

The online version of the original article can be found at https://doi.org/10.1007/s12142-006-1018-3

Melanie Adrian

melanie.adrian@carleton.ca

1 Carleton University, Ottawa, Canada 